\title{
Technology and English Language Teaching (ELT)
}

\author{
Akram Kazemi (Corresponding Author) \\ Department of Foreign Languages, Islamic Azad University, Kerman Branch, Kerman, Iran \\ E-mail: aky.kazemi@gmail.com \\ Mehry Haddad Narafshan \\ Department of Foreign Languages, Islamic Azad University, Kerman Branch, Kerman, Iran
}

Doi:10.7575/aiac.alls.v.5n.6p.60

URL: http://dx.doi.org/10.7575/aiac.alls.v.5n.6p.60
Received: $14 / 08 / 2014$

Accepted: 30/09/2014

\begin{abstract}
This paper is a try to investigate the attitudes of English language university teachers in Kerman (Iran) toward computer technology and find the hidden factors that make university teachers avoid using technology in English language teaching. 30 university teachers participated in this study. A questionnaire and semi-structured interview were used in order to collect the data. Both descriptive and inferential statistics as well as content analysis were conducted to analyze the data. The findings of the study revealed that a great majority of university teachers attribute positive remarks for integrating technology in language teaching. However, they get difficulty in integrating technology into their instruction effectively.
\end{abstract}

Keywords: Computer Assisted Language Learning (CALL), English Language Teaching (ELT)

\section{Introduction}

It is undeniable that we now live in a world in which technology has emerged in every aspect of our lives. Technology is wonderfully becoming highly significant in both our personal and professional lives, and our learners are using technology more and more. There is no doubt that technology in language learning is not new. Indeed, it has been around in language teaching for decades- one might argue for centuries, if we consider the blackboard as a form of technology. Tape recorders, language laboratories and videos have been in use since the 1960s and 1970s, and are still being used in classrooms around the world. Computer -based materials for language teaching, often referred to CALL (computer Assisted Language Learning), appeared in the early 1980s. Apart from its time and labor -saving function, technology can also give the idea of variety and bring new opportunities to people; connecting them to new thoughts and to people they otherwise might not have met. This increase in the availability of technology has led to an explosion of interest in its use in the language classroom.

In order for learning technology to be successful, it should be integrated into the curriculum (Graham Stanley, 2013). The main challenge in terms of keeping things fresh, especially in teaching has been getting a hold of new technology and mastering new technological things. Use of CALL for the teaching activities has become a widely acceptable way of knowledge transfer because of the flexibility and standardization of the overall educational process they offer. It is more significant especially to the professors who are the main source of knowledge at university. It is clear that there is a need to focus on faculty attitudes and affecting participation of them in e-learning, web-based teaching using technology in teaching-learning process. Few years ago using computer used to be the concern of those teachers who were familiar with computers .But using computer assisted language learning(CALL) has received attention of many English and foreign language instructors and also SLA researchers. (Kawase 2005; Beauvois, 1992; Chappell, 2001; Chun, 1994; Dhaif,1989; Kern, 1998; Kern \& Warschauer, 2000; Loewen \& Erlam, 2006; Sauro, 2009; Smith, 2003; Smith, 2004; Sullivan, \& Pratt, 1996; Warschauer, 1996a and 1996b; Warschauer, 1997; Razagifard \& Rahimpour, 2010). Teachers should become effective agents to be able to use CALL tools in the classroom, which is possible via positive teacher attitude thereby adopters feel more comfortable with using them and usually integrate them into their teaching (Bullock, 2004; \& Ker saint et al, 2003). Positive attitudes often stimulate teachers with less technology knowledge to learn the required skills for employing CALL -based tasks in the classroom setting. Although computer based materials for language teaching (Computer Assisted Language Learning), appeared in the early 1980s, it is not widespread .Most of the professors have understood CALL just as web -based materials, and they think of multiple computers for each student. This study wants to show professors that it's not necessary for them to have multiple computers, but most of the time just one computer or even a laptop computer and speakers in the classroom can suffice for implementing CALL in the classroom. In this study, we focus on studying the factors related to the attitude of professors' toward using technology in instruction. 


\section{Review of literature}

Computer-Assisted Language Learning (CALL) is a technique for using technology in the field of language learning (Januszewski \& Molenda, 2008). According to Wikipedia encyclopedia (2005), CALL is defined as an approach to language teaching and learning in which computer technology is used as an aid to the presentation, reinforcement, and assessment of material to be learned, usually including a substantial interactive element. In the light of this definition and for the purpose of this study, the CALL refers to the use of multimedia CD-ROM combining text, pictures, audio, and video files for the purpose of teaching English as a second language. Many studies worldwide have been conducted to investigate the effect of CALL on learning languages. Research results demonstrated a positive effect of CALL on students' learning and competency (Almekhlafi, 2006; Ertmer, Ottenbreit-Leftwich \& York, 2006; Benson \& Mekolichick, 2007; Teo, 2009). In other words, CALL has gained considerable attention from various entities including researchers and writers. As a recent educational innovation, the computerization of education is a sophisticated process where many agents play a role. Forces at the micro-level of the educational system (teachers and students) may be impressive in facilitating or impeding changes that are outside the control of the ministries of education (Pelgrum, 2001). Unfortunately, much of the researches on computer uses in education has ignored teachers' attitude toward the new machines (Harper, 1987).

Recent studies have shown that the successful implementation of educational technologies depends largely on the attitudes of educators, who eventually determine how they are used in the classroom. Bullock (2004) found that teachers' attitudes are a major enabling or disabling factor in the adoption of technology. Similarly, Kersaint, Horton, Stohl, and Garofalo (2003) found that teachers who have positive attitudes toward technology feel more comfortable with using it and usually incorporate it into their teaching. In fact, Woodrow (1992) asserted that any successful transformation in educational practice requires the development of positive users' attitude toward the new technology. The development of teachers' positive attitudes toward CALL is a key factor not only for enhancing computer integration but also for avoiding teachers' resistance to computer use (Watson, 1998). Watson (1998) warns against the severance of the innovation from the classroom teacher and the idea that "the teacher is an empty vessel into which this externally defined innovation must be poured. Knezek and Christensen (2002) analysis of several major cross-cultural studies completed during the 1990s and related to CALL in education suggested that teachers advance in technology integration through a set of well defined stages, which sometimes require changes in attitude more so than skills. If we examine works such as Liu et al. (2002) where the authors present a review of the research on CALL from 1990 to 2000. Out of the 70 articles studied by Liu and her colleagues, 44 dealt with the effectiveness of CALL in language teaching vs. traditional teaching, 15 dealt with how to use CALL more effectively, and the other 11 dealt with students' attitude to using CALL. Even when we review more recent studies, we find that these three key areas continue being the main focus for researchers, as we can see in Aydin and Genç (2011), and in Heift and Schulze (2012). There is, however, one key element which has been ignored to a great degree in most studies despite its importance in the classroom; the professors. Professors and lecturers are the ones in charge of incorporating CALL into their classroom, and as Sagarra and Zapata (2008) explained, the success of CALL is linked to the abilities of those who manage the course.

\section{Methodology}

The participants of this study were 30 professors at Islamic Azad university \& Shahid Bahonnar university in Kerman (Iran). In this study, both quantitative and qualitative data collection instruments (a questionnaire and a semi-structured interview) were employed in order to collect the data. Descriptive and inferential data analysis procedures were used to analyze the data gathered via the questionnaire. The data was analyzed using SPSS and content analysis was conducted in order to analyze the data collected through the semi-structured interview.

\section{Results and Discussion}

This study aimed at examining the factors affecting the perceptions and behaviors of English professors which make them avoid using technology in their teaching process. More specifically, the following six aspects were investigated in terms of six different variables:

1. English language professors' computer literacy

2. Professors interest toward computers and technology use in their teaching process

3. Professors self-confidence in technology use in teaching activities

4. The attitudes of English professors toward CALL and whether using computer is a waste of time

5. The attitudes of English language teachers toward the fear of using computers in educational settings, especially in instruction

6. The attitudes of English language professors toward available facilities and if they have received any training 
Table 4.1 Computer Literacy

\begin{tabular}{|c|c|c|c|c|c|c|c|c|}
\hline $\begin{array}{l}\text { Item } \\
\text { No }\end{array}$ & computer literacy & & $\begin{array}{l}\text { Strongly } \\
\text { Disagree }\end{array}$ & Disagree & Neutral & Agree & $\begin{array}{l}\text { Strongly } \\
\text { Agree }\end{array}$ & Total \\
\hline \multirow[t]{2}{*}{1.} & \multirow{2}{*}{$\begin{array}{l}\text { 1. Since teaching via a computer is a } \\
\text { little complicated so using it in the } \\
\text { classroom would be very hard for me. }\end{array}$} & Frequency & 11 & 9 & 3 & 6 & 1 & 30 \\
\hline & & Percent & 36.66 & 30 & 10 & 20 & 3.33 & 100 \\
\hline \multirow[t]{2}{*}{2.} & \multirow{2}{*}{$\begin{array}{l}\text { 2. Using computer needs master of } \\
\text { knowledge and I'm not the type to do } \\
\text { well with computer. }\end{array}$} & Frequency & 14 & 9 & 1 & 2 & 4 & 30 \\
\hline & & Percent & 46.66 & 30 & 3.33 & 6.66 & 13.3 & 100 \\
\hline \multirow[t]{2}{*}{3.} & \multirow{2}{*}{$\begin{array}{l}\text { 4. I use computers just for simple } \\
\text { applications like word processing, } \\
\text { spreadsheet, etc. not for other } \\
\text { purposes. }\end{array}$} & Frequency & 1 & 1 & 1 & 12 & 15 & 30 \\
\hline & & Percent & 3.33 & 3.33 & 3.33 & 40 & 50 & 100 \\
\hline \multirow[t]{2}{*}{4.} & \multirow{2}{*}{$\begin{array}{l}\text { 5. I t'donhave enough computer } \\
\text { integration literacy but tobe used in } \\
\text { the classroom curriculum. }\end{array}$} & Frequency & 3 & 4 & 0 & 13 & 10 & 30 \\
\hline & & Percent & 10 & 13.33 & 0 & 43.33 & 33.33 & 100 \\
\hline \multirow[t]{2}{*}{5.} & \multirow{2}{*}{$\begin{array}{l}\text { 26. I rarely have a clear and coherent } \\
\text { sense of the reasons for educational } \\
\text { change. }\end{array}$} & Frequency & 4 & 14 & 6 & 3 & 3 & 30 \\
\hline & & Percent & 13.33 & 46.66 & 20 & 10 & 10 & 100 \\
\hline
\end{tabular}

Table 4.2 Computer Interest

\begin{tabular}{|c|c|c|c|c|c|c|c|c|}
\hline $\begin{array}{c}\text { Item } \\
\text { No }\end{array}$ & Computer Interest & & $\begin{array}{l}\text { Strongly } \\
\text { Disagree }\end{array}$ & Disagree & Neutral & Agree & $\begin{array}{l}\text { Strongly } \\
\text { Agree }\end{array}$ & Total \\
\hline \multirow[t]{2}{*}{1.} & 11. Computers interest me little. & Frequency & 6 & 12 & 1 & 8 & 3 & 30 \\
\hline & & Percent & 20 & 40 & 3.33 & 26.66 & 10 & 100 \\
\hline \multirow[t]{2}{*}{2.} & $\begin{array}{l}\text { 12. Anything computer can be used } \\
\text { for, I can do just as well in some }\end{array}$ & Frequency & 4 & 10 & 7 & 8 & 1 & 30 \\
\hline & other way. & Percent & 13.33 & 33.33 & 23.33 & 26.66 & 3.33 & 100 \\
\hline \multirow[t]{2}{*}{3.} & $\begin{array}{l}\text { 15. I would like working with a } \\
\text { computer during my teaching }\end{array}$ & Frequency & 4 & 7 & 1 & 10 & 8 & 30 \\
\hline & & Percent & 13.33 & 23.33 & 3.33 & 3.33 & 26.66 & 100 \\
\hline \multirow[t]{2}{*}{4.} & $\begin{array}{l}\text { 13. I look forward to using computer } \\
\text { on my job. }\end{array}$ & Frequency & 5 & 2 & 3 & 11 & 9 & 30 \\
\hline & & Percent & 16.66 & 6.66 & 10 & 36.66 & 30 & 100 \\
\hline \multirow[t]{2}{*}{5.} & $\begin{array}{l}3.1 \text { have never used a computer in } \\
\text { my teaching process but I would like }\end{array}$ & Frequency & 16 & 7 & 1 & 4 & 2 & 30 \\
\hline & to reant. & Percent & 53.33 & 23.33 & 3.33 & 6.66 & 6.66 & 100 \\
\hline
\end{tabular}


Table 4.3 Computer Self confidence

\begin{tabular}{|c|c|c|c|c|c|c|c|c|}
\hline $\begin{array}{r}\text { Item } \\
\text { No }\end{array}$ & Computer Self-confidence & & $\begin{array}{l}\text { Strongly } \\
\text { Disagree }\end{array}$ & Disagree & Neutral & Agree & $\begin{array}{c}\text { Strongly } \\
\text { Agree }\end{array}$ & Total \\
\hline \multirow[t]{2}{*}{1.} & \multirow[t]{2}{*}{$\begin{array}{l}\text { 6. I can't show myself as a successful } \\
\text { teacher when I use computer }\end{array}$} & Frequency & 4 & 8 & 7 & 11 & 0 & 30 \\
\hline & & Percent & 13.33 & 26.66 & 23.33 & 36.66 & 0 & 100 \\
\hline \multirow[t]{2}{*}{2.} & \multirow{2}{*}{$\begin{array}{l}\text { 14. Since I may face a problem I } \\
\text { would never start a subject where I } \\
\text { had to work with computer. }\end{array}$} & Frequency & 2 & 6 & 1 & 9 & 12 & 30 \\
\hline & & Percent & 6.66 & 20 & 3.33 & 30 & 40 & 100 \\
\hline \multirow[t]{2}{*}{3.} & \multirow{2}{*}{$\begin{array}{l}\text { 16. I have a lot of self-confidence } \\
\text { when it comes to work with } \\
\text { computers. }\end{array}$} & Frequency & 6 & 8 & 5 & 8 & 3 & 30 \\
\hline & & Percent & 20 & 26.66 & 16.66 & 26.66 & 43.33 & 100 \\
\hline \multirow[t]{2}{*}{4.} & \multirow{2}{*}{$\begin{array}{l}\text { 21. My students know so much more } \\
\text { about computers than I do, so I } \\
\text { cannot keep up with them. }\end{array}$} & Frequency & 2 & 3 & 0 & 14 & 11 & 30 \\
\hline & & Percent & 6.66 & 10 & 0 & 46.66 & 36.66 & 100 \\
\hline \multirow[t]{2}{*}{5.} & \multirow{2}{*}{$\begin{array}{l}\text { 28. I hardly believe I am able to } \\
\text { make effective use of technology in } \\
\text { everyday classroom teaching. }\end{array}$} & Frequency & 2 & 1 & 1 & 11 & 15 & 30 \\
\hline & & Percent & 6.66 & 3.33 & 3.33 & 36.66 & 50 & 100 \\
\hline
\end{tabular}

Table 4.4 Computer and Waste of Time

\begin{tabular}{|c|c|c|c|c|c|c|c|c|}
\hline $\begin{array}{r}\text { Item } \\
\text { No }\end{array}$ & Computer and Waste of Time & & $\begin{array}{l}\text { Strongly } \\
\text { Disagree }\end{array}$ & Disagree & Neutral & Agree & $\begin{array}{l}\text { Strongly } \\
\text { Agree }\end{array}$ & Total \\
\hline \multirow[t]{2}{*}{1.} & $\begin{array}{l}\text { 7. I think it takes a long time to finish } \\
\text { my teaching by computer. }\end{array}$ & Frequency & 1 & 9 & 4 & 13 & 3 & 30 \\
\hline & & Percent & 3.33 & 30 & 13.33 & 43.33 & 10 & 100 \\
\hline \multirow[t]{2}{*}{2.} & $\begin{array}{l}\text { 8. Teaching via a computer is a waste } \\
\text { of time. }\end{array}$ & Frequency & 5 & 2 & 2 & 12 & 9 & 30 \\
\hline & & Percent & 16.66 & 6.66 & 6.66 & 40 & 30 & 100 \\
\hline \multirow[t]{2}{*}{3.} & $\begin{array}{l}\text { 9. By using text books in the } \\
\text { classroom I can use my time more }\end{array}$ & Frequency & 2 & 7 & 0 & 12 & 9 & 30 \\
\hline & approprialery tran using a computer. & Percent & 6.66 & 23.33 & 0 & 40 & 30 & 100 \\
\hline \multirow[t]{2}{*}{4.} & $\begin{array}{l}\text { 22. It takes a lot of time to bring } \\
\text { required equipment in the classroom. }\end{array}$ & Frequency & 2 & 7 & 0 & 9 & 12 & 30 \\
\hline & & Percent & 6.66 & 23.33 & 0 & 30 & 40 & 100 \\
\hline \multirow[t]{2}{*}{5.} & $\begin{array}{l}\text { 24. I'd like to use computers more, } \\
\text { but preparing materials is so time }\end{array}$ & Frequency & 0 & 3 & 4 & 18 & 5 & 30 \\
\hline & consuming & Percent & 0 & 10 & 13.33 & 60 & 16.66 & 100 \\
\hline
\end{tabular}


Table 4.5 Computer and Technophobia

\begin{tabular}{|c|c|c|c|c|c|c|c|c|}
\hline $\begin{array}{l}\text { Item } \\
\text { No }\end{array}$ & Computer and Technophobia & & $\begin{array}{l}\text { Strongly } \\
\text { Disagree }\end{array}$ & Disagree & Neutral & Agree & $\begin{array}{c}\text { Strongly } \\
\text { Agree }\end{array}$ & Total \\
\hline \multirow[t]{2}{*}{1.} & \multirow{2}{*}{$\begin{array}{l}\text { 17. I hesitate to use a computer for } \\
\text { fear of making mistakes I cannot } \\
\text { correct. }\end{array}$} & Frequency & 7 & 12 & 0 & 6 & 5 & 30 \\
\hline & & Percent & 23.33 & 40 & 0 & 20 & 16.66 & 100 \\
\hline \multirow[t]{2}{*}{2.} & \multirow{2}{*}{$\begin{array}{l}\text { 20. I'm a digital immigrant so I } \\
\text { prefer to avoid using technology }\end{array}$} & Frequency & 9 & 10 & 2 & 5 & 4 & 30 \\
\hline & & Percent & 30 & 33.33 & 6.66 & 16.66 & 13.33 & 100 \\
\hline \multirow[t]{2}{*}{3.} & \multirow{2}{*}{$\begin{array}{l}\text { 23. I have had a negative experience } \\
\text { with technology in the past. }\end{array}$} & Frequency & 13 & 14 & 1 & 0 & 2 & 30 \\
\hline & & Percent & 43.33 & 46.66 & 3.33 & 0 & 6.66 & 100 \\
\hline \multirow[t]{2}{*}{4.} & \multirow{2}{*}{$\begin{array}{l}25 \text {. By including technology in the } \\
\text { classroom the role of the teacher will } \\
\text { be diminished. }\end{array}$} & Frequency & 6 & 13 & 4 & 5 & 2 & 30 \\
\hline & & Percent & 20 & 43.33 & 13.33 & 16.66 & 6.66 & 100 \\
\hline \multirow[t]{2}{*}{5.} & \multirow{2}{*}{$\begin{array}{l}\text { 27. By using computer I can hardly } \\
\text { have a controlled learning } \\
\text { environment. }\end{array}$} & Frequency & 4 & 10 & 4 & 11 & 1 & 30 \\
\hline & & Percent & 13.33 & 33.33 & 13.33 & 36.66 & 3.33 & 100 \\
\hline
\end{tabular}

Table 4.6 Computer and a Facility

\begin{tabular}{|c|c|c|c|c|c|c|c|c|}
\hline Item & & & Strongly & Disagree & Neutral & Agree & Strongly & Total \\
\hline \multirow[t]{2}{*}{1.} & \multirow{2}{*}{$\begin{array}{l}\text { 10. Since I have never received any } \\
\text { training I expect to have little use for } \\
\text { computers in my teaching process. }\end{array}$} & Frequency & 4 & 9 & 4 & 10 & 3 & 30 \\
\hline & & Percent & 13.33 & 30 & 13.33 & 33.33 & 10 & 100 \\
\hline \multirow[t]{2}{*}{2.} & \multirow{2}{*}{$\begin{array}{l}\text { 18. Usefulness of technology has } \\
\text { been reduced by a lack of facilities. }\end{array}$} & Frequency & 1 & 2 & 0 & 9 & 18 & 30 \\
\hline & & Percent & 3.33 & 6.66 & 0 & 30 & 60 & 100 \\
\hline \multirow[t]{2}{*}{3.} & \multirow{2}{*}{$\begin{array}{l}\text { 19. Usefulness of technology has } \\
\text { been reduced by a lack of training }\end{array}$} & Frequency & 1 & 0 & 1 & 11 & 17 & 30 \\
\hline & & Percent & 3.33 & 0 & 3.33 & 66 & 56.66 & 100 \\
\hline \multirow[t]{2}{*}{4.} & \multirow{2}{*}{$\begin{array}{l}\text { 29. I like to use technology, but I } \\
\text { don't know what to do. }\end{array}$} & Frequency & 2 & 7 & 2 & 7 & 12 & 30 \\
\hline & & Percent & 6.66 & 23.33 & 6.66 & 23.33 & 40 & 100 \\
\hline \multirow[t]{2}{*}{5.} & $\begin{array}{l}\text { 30. Limited number of computers for } \\
\text { students make Computer Assisted }\end{array}$ & Frequency & 5 & 3 & 7 & 2 & 13 & 30 \\
\hline & $\begin{array}{l}\text { Language Learning (CALL) less } \\
\text { beneficial for our students. }\end{array}$ & Percent & 16.66 & 10 & 23.33 & 6.66 & 43.33 & 100 \\
\hline
\end{tabular}

\section{Conclusion}

According to the results of the quantitative questionnaire, it was found out that most of professors were knowledgeable, but their level of literacy was different. However, when their computer literacy was considered, it was understood that they use computers and the Internet at low-levels. Teachers usually admit that they do in fact know a bit about technology. They usually know how to use e-mail, word processing program and how to use the internet. This knowledge is certainly enough to get started with using technology in the classroom, and the learners are delighted to be called upon to help out, and to get a chance to demonstrate their skills and knowledge in this area. Some computer based work can be done alone, for example using CD-ROMs. The CALL approach is one that is still found on many 
published CD-ROMs for language teaching. Although the use of ICT by language teachers is not still widespread, the use of technology in the classroom is becoming increasingly important, and it will become a normal part of ELT practice in the coming years because younger learners are growing up with technology, and it is a natural and integrated part of their lives. Another significant comment of the interview data is that English professors used computers more for personal purposes. However, they could not make use of computers effectively for the tasks which included the students and classroom activities. Besides, few teachers used web blogs in their language teaching practices.

According to the results of the quantitative questionnaire, it was found out that majority of the professors totally were interested in using computers and computer technologies. As we know professor have varying level of interest to computer and technology. As access to Information and Communication Technology (ICT) has become more widespread, so CALL has moved beyond the use of computer programs to embrace the use of internet and web-based tools. Using a range of ICT tools can give learners exposure to and practice in all of the four language skills -speaking, listening, reading and writing.

According to the descriptive statistics of the questionnaire data showed that, English teachers used computers rarely in their classroom. However, when their usage levels were considered, it was understood that different factors make them avoid using computer .One of these factors was professors' self-confidence to use computer or other resources. According to the quantitative data from questionnaire, it was clarified that most of these participants do not have the required self-confidence to use technology. According to their comments in their interviews, some of them think by using computer in the classroom they may face problems that they cannot correct. The others think that because their learners are digital natives and the professors are digital immigrants, so they know less than their learners, and consequently they will lose their self-confidence .They are worried about failing technology, as well as going something wrong, and also the professors don't have the required skills in implementing CALL in the classroom curriculum.If professors try to make themselves strong in technical skills, surely their self-confidence will improve, besides after having such an experience for one or two sessions after that this problem will be diminished.

One of the most important features of a computer is the access to information it provides. Because the internet acts as a virtual library, students can have access to nearly any piece of information imaginable. This can be highly advantageous in the classroom as it can enhance the information on any classroom subject. Computers also save time in many ways. Not only can computers access millions of pages of information on the Internet, but also they can do this in an incredibly fast time. What once might have taken hours of library research might now only take a few minutes on the computer.

In addition to the Internet, tools such as word processors, presentation software, and spreadsheets have added efficiency. They eliminate much of the time that traditional writing, presentations, and creating tables and forms once required. According to the obtained statistics from analyzing this question a considerable number of professors believe that using computer in the classroom is wasting time .According to their comments in their interviews, by including any source of technology in the classroom the speed of teaching process will slow down. Some of them say that they would like to use computers, but preparing materials is so time- consuming. The answer is here that typically, a course book will have its own web pages on the publishers' website; a list of recommended websites to visit for each unit, a CDROM and / or DVD, and occasionally teacher support online, in the form of frequently asked questions (FAQs), or discussion forum.

Preparing materials is not as time- consuming as paper -based materials. The findings in this study showed that professors still prefer textbooks to technology. It is worth mentioning that traditional materials (blackboard /whiteboard or a course book) can never be replaced by using computer or other technological devices. Technology can be used to complete your activities in the classroom .Imagine that a unit in the course book deals with animals in the danger of extinction. Technology can be used to do complementary activities such as data collection, or a webquest on animals in danger of extinction. The teacher can produce additional materials to review course book material on the topic, too.

There is a tendency to call computer users technophobes or technogeeks (a term for technology enthusiast), the truth is that most of us probably fall somewhere between the extremes. Teachers who have had negative experience with technology in the past often express dislike and fear of computer. The qualitative data yielded invaluable findings regarding English professors' technophobia and their use of computer technology. According to the results of the quantitative questionnaire, it was found out that English professors overall had positive attitudes toward computers and computer technologies and they do not feel like having technophobia. The best way to address the situation is to make teachers aware that they already have certain technical skills-they probably know how to use a tape recorder in the classroom, for example, and often already use technology in their personal lives, such as MP3 player, the internet or email. In other words, rather than dismissing very real fears, these need to be acknowledged and addressed. The technophobic teacher needs to be encouraged to get started by implementing simple, undemanding technology with learners. Using a ready - made webquest from the Internet, for example, is a good way to start. Teachers also need to realize that technology does and will break down occasionally, and that it is always good to have a lesson plan that does not require the use of technology, and sometimes professors can ask learners to help out if technology fails. Select a volunteer or two to help sort out the problem, and always have an alternative activity/lesson plan ready. In addition, providing good training in the use of technology in the classroom is a key to encourage the long-term acceptance and the use of technology by technophobic teachers.

The pedagogical exploitation of technology depends as much on the availability of teaching resources as it does on teachers' understanding of how best to use the technology(Schmid \& Hazerbrouck,2010). This trends to indicate that 
training, therefore, is the key to effective use of indeed any technology. As the quantitative figures of questionnaire besides the professors' comments in their interviews show, a considerable number of the participants were firmly believed that they have no facility and no training .This was an often-heard remark in the process of doing this study. Most of the professors said that we need a hall with computers for each student. There is a language lab in both Azad \& Bahonnar universities, but the problem is here that professors do not use these facilities properly as well. There was a DVD player in the professors' offices in Azad \& Bahonnar universities, but according to the data obtained from students' questionnaire, none of them uses it frequently. They have never asked for more facilities, because they have never thought of including technology in their classroom.

In addition to teachers' own perceptions about technology and computers, it was observed that external factors are quite influential on teachers' use of computers and technology. The common factor is the lack of technological tools that can be utilized while teaching classes. The interview data suggested that some of professor use projectors in order to present the course content to their students. However, it was also found out that just a few respondents have projectors in their classes every time. A majority of English teachers had to share some limited projectors with their colleagues. Because there are limited technological tools, this insufficiency sometimes affects professors' overall use of computers in their classes. Another paramount factor that hampers the use of technology by professors as data collected from professors showed that teachers do have positive attitudes toward computers and technology, but their adoption of computers and their use of technology in their language teaching practices do not correlate with their positive attitudes. They are using computers at low-levels which do not require complex applications and their use of technology cannot enhance interactive student participation in language learning and teaching process. However, the more teachers have access to computers and make use of them, the better they will learn how they can conduct more complicated tasks using technology in their language teaching practices (Ertmer, 2005\&Wozney, 2006).

\section{References}

Ahmad, K., Corbett, G., Rogers, M. and Sussex, R.(1985). Computers, language learning and language teaching. Cambridge: Cambridge University Press

Abrams, Z. I. (2003). The Effect of Synchronous and Asynchronous CMC on Oral Performance in German.

Albirini, A. (2004). An exploration of the factors associated with the attitudes of high school EFL teachers in Syria toward information and communication technology. (Doctoral Dissertation, the Ohio State University).

Becker, H. J. (2001). How are teachers using technology in instruction?

Beauvois, M. H. (1992). Computer-assisted classroom discussion in the foreign language classroom: Conversation in slow motion. Foreign Language Annals, 25, 455-464.

Bryman, A. (2006).Social research methods (2nd ed). New York: Oxford University Press

Chin, S.S. \& Hortin, J.A. (1993)Language Learning and Technology.

Chen, Y. (2008). A mixed-method study of EFL teachers" Internet use in language instruction.

Chapelle, C. (2001). Computer applications in second language acquisition: Foundations for teaching, testing, and research. New York: Cambridge University Press.

Chapelle, C.A. (2007). Technology and second language acquisition.

Chun, D. M. (1994). Using computer networking to facilitate the acquisition of interactive competence system, 22, 1731.

Cuban, L, Kirkpatrick, H. \& Peck, C. (2001). High Access and Low Use of Technologies in High School Classrooms.

Dhaif, H. A. (1989).Can computers teach languages? English Teaching Forum. 27(3), 17-19.

Dörnyei, Z. (2007). Research methods in applied linguistics.

Doctoral Dissertation, Nova University. Brown, D. \& Warschauer, M. (2006).

Gitsaki, C. and Taylor (1999). Internet-based activities for the ESL classroom. ReCALL, 11,1,47-57.

Gunduz, N. (2005). Computer assisted language learning. Retrieved April 25, 2009, from http://jlls.org/Issues/Volume1/No.2/nazligunduz.pdf

Gavin Dudney (2007). The internet and the language classroom.

Gavin Dudney \& Nicky Hockly (2008). How to teach English with technology.

Garrett, N. (1991). Technology in the service of language learning.

Greene, J. C., Caracelli, V. J. \& Graham, W. F. (1989).Calculating, interpreting, and reporting Cronbach's alpha reliability coefficient for Likert-type scales. 2003 Midwest Research-to-Practice Conference in Adult, Continuing, and Community Education, The Ohio State University, Columbus, OH.

Gall, M.D., Gall, J.P., \& Borg, W.R. (2007).Computer Assisted Language Learning.

Guba, E.G. (1990). Educational Evaluation and Policy Analysis, 11(3), 255-274. The paradigm dialog.

Harrison, R. (1998). The evolution of networked computing in the teaching of Japanese as a foreign language. Computer Assisted Language Learning, 11, 4, 437-452.

Holmes, B. (1998). Initial perceptions of CALL by Japanese university students. Computer Assisted Language Learning, 11,4,397-409. 
Hoven, D. (1999). A model of listening and viewing comprehension in multimedia environments. Language Learning and Technology, 3, 1, 88-103.

Jones, C. \& Fortescue, S. (1987). Using computers in language classroom. London: Longman.

Johnson, R.B. \& Onwuegbuzie, A.J. \& Turner, L.A. (2007). Mixed methods research: A research paradigm whose time has come.

Jaber,W.E. (1997). A survey of factors which influence teachers' use of computer-based technology.

Kaliski, T. (1992). Computer-assisted Language Learning (CALL). In Peter Roach (Ed.)Computing in linguistics \& phonetics. PP. 95-109. London: Academic Press.

Kawase, A. (2005). Second language acquisition and synchronous computer mediated communication. Retrieved April 17, 2009, from http://www.tc.columbia.edu/tesolalwebjournal

Kern, R. (1998). Technology, social interaction, and FL literacy. In J. A. Muyskens (Ed.) New ways of learning and teaching: Focus on technology and foreign language education (pp. 57-92). Boston: Heinle \& Heinle.

Kern, R., \& Warschauer, M. (2000). Theory and practice of network-based language teaching. In M. Warschauer \& R. Kern (Eds.), Network-based language teaching: concepts and practice (pp. 1-19). New York: Cambridge University Press.

Kern, R. (2006). How teachers integrate technology and their beliefs about learning: Is there a connection? Journal of Technology and Teacher Education.

Kenning, M.J. \& Kenning, M.M. (1984). Introduction to computer assisted language teaching. Oxford: Oxford University Press.

Kenning, M. M. and Kenning, M. J. (1990). Computers and language learning: current heory and practice. New York: Ellis Harwood.

Kubota, R. (1999). Word processing and WWW projects in a college Japanese language class. Foreign Language Annals, 32, 2, 205-218.

Kitade, K. (2000). L2 learners" discourse and SLA theories in CMC: Collaborative interaction in Internet chat.

Lantolf, J. P. (2001). Sociocultural theory and SLA. In R. B. Kaplan (ed.), The Oxford handbook of applied linguistics.

Leech, G. and Candlin, C. (1986). Computer in English language teaching and research. London: Longman.

Levy, M. (1999). Theory and design in multimedia CALL project in cross- $\quad$ cultural pragmatics. Computer Assisted-Language Learning, 12, 1, 29-57.

Loewen, S., \& Erlam, R. (2006). Corrective feedback in the chat room: An experimental study. Computer Assisted Language Learning 19(1), 1-14. language grammar. Language Learning \& Technology, 13, 96-120.

Long, M.H. (1996).Computers \& Education .

Nunan, D. (1999). A footnote in the world of ideas: graduate study through the Internet. Language Learning and Technology. 3, 1, 52-74.

Phillips, M. (1987). Communicative language learning and the micro-computer. London: British Council.

Razagifard, P. and Rahimpour, M. (2010). The effect of computer-mediated corrective feedback on the language learners' grammar. International Journal of Instructional Technology and Distance Learning. Vol. 7, No. 5.

Sauro, S. (2009). Computer-mediated corrective feedback and the development of second language grammar. Language Learning \& Technology, 13, 96-120.

Smith, B. (2003). Computer-mediated negotiated interaction: An expanded model. The Modern Language Journal, 87(1), 38-57.

Smith, B. (2004). Computer-mediated negotiated interaction and lexical acquisition. Studies in Second Language Acquisition, 26(3), 365-398.

Sullivan, N., \& Pratt, E. (1996). A comparative study of two ESL writing environments: A computer assisted classroom and a traditional oral classroom. System, 29, 491-501.

Vanparys, J. and Baten, L. (1999). How to offer real help to grammar learners. ReCALL, 11, 1, $125-132$.

Underwood, J. (1984). Linguistics, computers, and language teacher: a communicative approach. Rowley. MA: Newbury House.

Warschauer, M. and Healey, D. (1998). Computers and language learning: an overview. Language Teach. 31 , 57-71.

Warschauer, M. (1997). Computer-mediated collaborative learning: Theory and practice. The Modern Language Journal, 81(4), 470-481.

Warschauer, M. (1996a). Computer-assisted language learning: an introduction. In S. Foctos (Ed.). Multimedia language teaching, 3-20. Tokyo: Logos.

Warschauer, M. (1996a). Computer-assisted language learning: An introduction. Retrieve April 18, 2009, from http://www.gse.uci.edu/faculty/markw/call.html

Warschauer, M. (1996c). Comparing face-to-face and electronic communication in the second language classroom. CALICO Journal, 13, 7-25. 